\title{
Morphological and genetic diversity of Euglena deses group (Euglenophyceae) with emphasis on cryptic species
}

\author{
Jong Im Kim ${ }^{1}$, Eric W. Linton ${ }^{2}$ and Woongghi Shin ${ }^{1, *}$ \\ ${ }^{1}$ Department of Biology, Chungnam National University, Daejeon 34134, Korea \\ ${ }^{2}$ Department of Biology, Central Michigan University, Mt. Pleasant, MI 48859, USA
}

The Euglena deses group are common freshwater species composed of E. adhaerens, E. carterae, E. deses, E. mutabilis, and $E$. satelles. These species are characterized by elongated cylindrical worm-like cell bodies and numerous discoid chloroplasts with a naked pyrenoid. To understand the cryptic diversity, species delimitation and phylogenetic relationships among members of the group, we analyzed morphological data (light and scanning electron microscopy) and molecular data (nuclear small subunit [SSU] and large subunit [LSU] rDNAs and plastid SSU and LSU rDNAs). Bayesian and maximum likelihood analyses based on the combined four-gene dataset resulted in a tree consisting of two major clades within the group. The first clade was composed of two subclades: the E. mutabilis subclade, and the E. satelles, E. carterae, and $E$. adhaerens subclade. The E. mutabilis subclade was characterized by a lateral canal opening at the anterior end and a single pellicular stria, whereas the E. satelles, E. carterae, and E. adhaerens subclade was characterized by an apical canal opening at the anterior end of the cell and double pellicular striae. The second clade consisted of 20 strains of E. deses, characterizing by a subapical canal opening at the anterior end and double pellicular striae, but they showed cell size variation and high genetic diversity. Species boundaries were tested using a Bayesian multi-locus species delimitation method, resulting in the recognition of five cryptic species within E. deses clade.

Key Words: Euglena deses group; molecular phylogeny; morphology; phylogeny; species delimitation

Abbreviations: LSU, large subunit; ML, maximum likelihood; MLBT, ML bootstrap support value; nr, nuclear; nt, nucleotide; PP, posterior probability; pt, plastid; SEM, scanning electron microscopy; SSU, small subunit

\section{INTRODUCTION}

The species delimitation is essential for both biologists and the general public because species are fundamental units to understand ecosystem and biodiversity assessments in most fields with living organisms. In addition, taxonomic rank is a language used by scientists to help the public recognize the diversity, ecology, distribution, and evolutionary history of living organisms. However, the morphologically similar and simple features in uni- cellular algal species can make it extremely difficult to perform species identification and delimitation. In microalgae, an insufficient number of morphological features that could be used to clearly distinguish one species from another enhances the problem of species delimitation. Hidden or cryptic, i.e., morphologically highly similar species, are frequently described in green algae (Lewis and Flechtner 2004, Fawley et al. 2011, Demchenko et al.
(9) This is an Open Access article distributed under the terms of the Creative Commons Attribution Non-Commercial License (http://creativecommons.org/licenses/by-nc/3.0/) which permits unrestricted non-commercial use, distribution, and reproduction in any medium, provided the original work is properly cited.
Received June 14, 2016, Accepted September 9, 2016

* Corresponding Author

E-mail: shinw@cnu.ac.kr

Tel: +82-42-821-6409, Fax: +82-42-822-9690 
2012), chrysophytes (Škaloud et al. 2012, 2014, Jo et al. 2013), and diatoms (Mann et al. 2004, Lundholm et al. 2012). This problem is particularly difficult in euglenoids where authors often struggle to differentiating hidden species morphologically, and thus define cryptic species according to the phylogenetic species concept (Kosmala et al. 2007b, 2009, Kim et al. 2013a, 2013b, Kim and Shin 2014).

Traditionally, the species of the Euglena deses group (i.e., E. adhaerens, E. carterae, E. deses, E. mutabilis, and E. satelles) were classified according to taxonomic systems based on morphological characteristics. Chu (1946) sorted these species into group II under the genus Euglena using the characteristics of chloroplast shape and number and the presence of a naked pyrenoid. Gojdics (1953) categorized these species into B or E groups according to the number, arrangement and shape of the chloroplasts. Pringsheim (1956) classified the $E$. deses group into the subgroup Serpentes based on cell shape, metabolic degree and chloroplast type. More recently, Zakryś (1986) arranged these species into both subgenera Discoglena and Calliglena based on characteristic features of the chloroplast, for example small, numerous discoid chloroplasts without pyrenoid and fewer discoid chloroplasts with a naked pyrenoid. Unfortunately, the taxonomy of these euglenoids has been depended mainly on morphological characteristics recognizable by light microscopy. However, for many of these species and varieties, it is difficult to distinguish details because of strong metabolic movements and similar morphological features. In addition, in old cells crowded with paramylon grains, the diagnostic features of the chloroplasts used to identify these species are masked, and a definitive identification of pyrenoids is inhibited. The use of fixatives and dyes as methods to identify these cells remains limited. However, transmission electron microscopy and scanning electron microscopy (SEM) have been increasingly applied to clarify details of cell organelles (Leedale 1967, 1982, Triemer 1980, Walne et al. 1986, Shin and Boo 2001, Zakryś et al. 2001, Kim and Shin 2007, Kusel-Fetzmann and Weidinger 2008, Monfils et al. 2011).

Molecular analyses have also been attempted to understand the phylogenetic relationships among euglenacean species, including species of the E. deses group (Marin et al. 2003, Shin and Triemer 2004, Triemer et al. 2006, Kim and Shin 2008, Kim et al. 2010, Linton et al. 2010, Karnkowska-Ishikawa et al. 2011). Recently, Karnkowska-Ishikawa et al. (2011) synonymized all morphological varieties of $E$. deses to only one species, based on a morphologically recognizable light microscopy character (periplast mucus papillae) and nuclear-encoded small subunit (nr SSU) rDNA sequence data, but recognized high genetic diversity and extreme variation in cell dimensions. However, that study was limited to only 10 cultured strains of the E. deses group and analyzed only partial nr SSU rDNA sequence data.

Euglena deses is a dominant freshwater species with many morphological varieties characterizing by an elongated cylindrical cell shape, strong metaboly, numerous discoid chloroplasts with a naked pyrenoid and rodshaped paramylon grain in the cytoplasm. Since Ehrenberg $(1835,1838)$ first established the species E. deses in drawings, other investigators have described many taxa with morphology similar to that of E. deses (Klebs 1883, Schmitz 1884, Lemmermann 1910, Playfair 1921, Wermel 1924, Mainx 1927, Fritsch et al. 1930, Braslavska-Spectorova 1937, Matvienko 1938, Pringsheim 1953, 1956, Popova 1955, 1966, Zakryś 1986, Shi 1989). However, there was little known about species limitation and phylogeny of $E$. deses based on morphological and molecular data. In this study, we focused on species delimitation of $E$. deses, one of the most common members of the genus Euglena. In particular, we aimed to 1) morphologically and genetically differentiate among the Euglena deses group, using 32 strains; 2) examine phylogenetic relationships of the species within group; 3 ) explore cryptic diversity of $E$. deses using species delimitation analyses. The present study will contribute to our understanding of the cryptic diversity of the E. deses group.

\section{MATERIALS AND METHODS}

\section{Strains and cultures}

The strain information and GenBank accession numbers are listed in Supplementary Table S1. Strains were either obtained from culture collections or were collected using a $20 \mu \mathrm{m}$ mesh plankton net (Bokyeong Co., Busan, Korea) from small ponds in the USA, the Philippines, Japan and Korea. All of the strains were grown in modified AF-6 medium (Watanabe and Hiroki 1997) and were maintained at $20-22^{\circ} \mathrm{C}$ under conditions of a $14: 10$ light : dark cycle with $30 \mu \mathrm{mol}$ photons $\mathrm{m}^{-2} \mathrm{~s}^{-1}$ from cool white fluorescent tubes.

\section{Strain identification and observation}

Culture strains were observed and identified under an Axio Imager A2 microscope (Carl Zeiss Inc., Hallberg- 
moos, Germany) equipped with differential interference contrast optics. Images were captured with an AxioCam HRc (Carl Zeiss Inc.) photomicrographic system attached to the microscope. For morphological measurements, we used 3-4-week-old cultures of each species. Cellular dimensions were determined by measuring 25-35 cells of each taxon from photographic images. The morphological features, the cell size and shape, paramylon type, canal position, caudal shape and pellicle structure, were analyzed (Table 1).

\section{Scanning electron microscopy}

To obtain fully extended cells, a small volume of cells in liquid medium (1-2 mL) was transferred into the bottom of a small petri dish containing a piece of filter paper saturated with $2 \% \mathrm{OsO}_{4}$ and mounted on the inner surface of the lid. The lid was then placed over the chamber, and the cells were fixed by $\mathrm{OsO}_{4}$ vapors for $10 \mathrm{~min}$. Four to five drops of $2 \% \mathrm{OsO}_{4}$ were added directly into the liquid medium, and the cells were fixed for another $30 \mathrm{~min}$. The cells were transferred onto 0.45 - $\mu$ m nylon membrane filters (Whatman International Ltd., Maidstone, UK), dehydrated with a graded series $(50,60,70,80,90$, and $100 \%)$ of ethyl alcohol or acetone and dried in a critical point dryer (HSP-2; Hitachi, Tokyo, Japan) with $\mathrm{CO}_{2}$. The filters were mounted on stubs and sputter-coated with platinum. The cells were viewed under a LEO-1530 FE-SEM (Carl Zeiss Inc., Hallbergmoos, Germany).

\section{DNA extraction, amplification, sequencing, and sequence alignments}

All 78 strains, including six outgroup taxa, were grown and harvested, and DNA was extracted from cultured cells as previously described (Kim and Shin 2008, Kim et al. 2010). The four genes were sequenced from plasmid-like chromosomes found in cytoplasmic SSU and large subunit (LSU) (Greenwood et al. 2001) and plastid-encoded SSU (pt SSU) and LSU rDNA genes (Kim and Shin 2008, Kim et al. 2013b). A total of 96 new sequences were generated, including 19 sequences of nr SSU, 21 sequences of $\mathrm{nr}$ LSU, 24 sequences of pt SSU, and 21 sequences of pt LSU rRNA genes. All sequences were aligned by eye using the Genetic Data Environment (GDE 2.4) program (Smith et al. 1994), using the secondary structure of the cytoplasmic SSU and LSU rRNA molecules of Euglena gracilis Klebs (Wuyts et al. 2001, Schnare and Gray 2011) as a guide. The conserved regions of the four genes were readily alignable across taxa and were used for the phy- logenetic analyses. All ambiguous positions excluded for the phylogenetic analyses and pair-wise comparisons.

\section{Phylogenetic analyses}

A combined dataset of 5,384 nucleotides (nr SSU, 1,653; nr LSU, 766; pt SSU, 1,336; pt LSU, 1,629) was generated for the phylogenetic analyses. The sequences of the six species of the family Phacaceae were used as outgroup taxa because these taxa were shown to represent a basal clade in previous molecular studies of photosynthetic euglenoids (Triemer et al. 2006, Kim and Shin 2008, Kim et al. 2010, Linton et al. 2010, Kim et al. 2015).

Bayesian analyses were performed using MrBayes 3.2 (Ronquist et al. 2012). A combined data analysis was performed using the four Metropolis-coupled Markov chain Monte Carlo $\left(\mathrm{MC}^{3}\right)$ with 10 million cycles for each chain. The trees were saved to a file every 1,000 cycles, and the burn-in point was identified graphically by tracking the likelihood values (TRACER v. 1.6; http://tree.bio.ed.ac. $\mathrm{uk} /$ software/tracer/).

The maximum likelihood (ML) phylogenetic analyses were performed using RAxML 8.1.20 (Stamatakis 2014) with the general time reversible plus Gamma (GTR + GAMMA) model. We used 1,000 independent tree inferences using the -\# option of the program to identify the best tree. The "-f a" option was used in RAxML for the simultaneous search for the best likelihood tree and rapid bootstrap analysis with "-\# 1,000" (1,000 bootstrap replications) with default options. Gamma correction values of the combined dataset were obtained automatically with the program (Supplementary Table S2). ML bootstrap support values (MLBT) of each monophyletic node calculated using 1,000 bootstrap replications under the same ML setting.

\section{DNA-based species delimitation}

We used a recently developed Bayesian method, Bayesian Phylogeography and Phylogenetics (BP\&P v3), which aims to detect signals of species divergence in multiple gene trees, even in the absence of monophyly, based on models combining species phylogeny and the ancestral coalescent process, and assuming no admixture following the speciation event (Yang and Rannala 2014). The marginal posterior probability of 5 -species scenario suggested by molecular data was estimated using the program. BP\&P gives the posterior probability of each delimited species and the posterior probability for the number of delimited species. A gamma prior $\mathrm{G}(1,10)$, with mean 


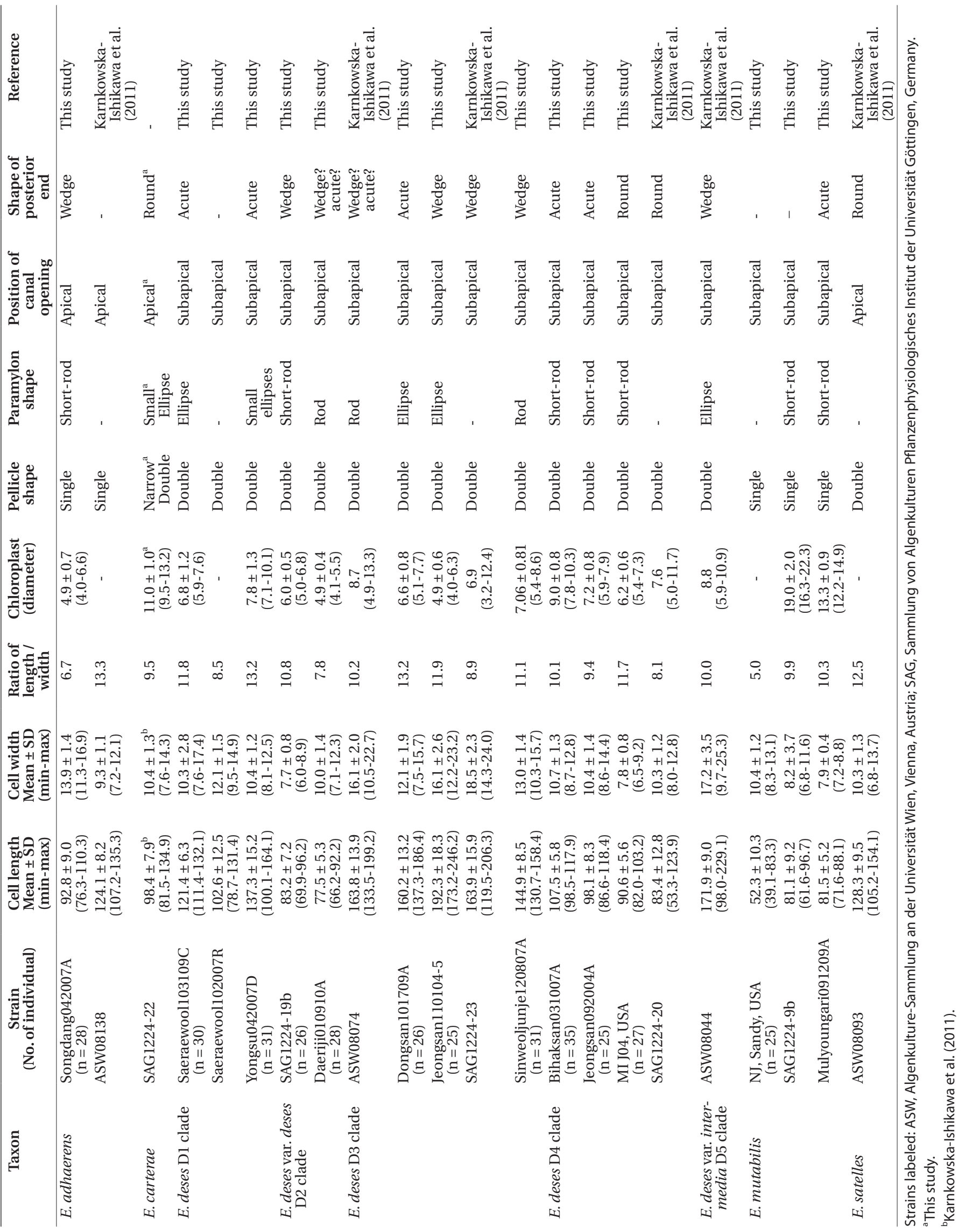


$1 / 10=0.1$ (one difference per $10 \mathrm{bp}$ ) was used on the population size parameters (s). The age of the root in the species tree $(\tau 0)$ was assigned the gamma prior $\mathrm{G}(2,2000)$ which means $0.1 \%$ of sequence divergence, while the other divergence time parameters were assigned the Dirichlet prior. Each analysis was run twice with $10^{6}$ generations to confirm consistency between runs. The burn-in point was identified graphically by tracking the likelihood values (TRACER v. 1.6; http://tree.bio.ed.ac.uk/software/ tracer/).

\section{RESULTS}

\section{Phylogenetic analyses}

The phylogenetic trees with supported values constructed from the Bayesian and RAxML analyses had identical tree topologies (Fig. 1). The Euglena deses group (E. adhaerens, E. carterae, E. deses, E. mutabilis, and E. satelles) was monophyletic with strong support values within the genus Euglena (posterior probability [PP], 1.00; MLBT, 100) and divided into two major clades. One clade consisted of the E. mutabilis subclade and the $E$. satelles and E. adhaerens subclade (PP, 1.00; MLBT, 83). The E. mutabilis subclade was composed of 8 strains and formed a monophyletic lineage with strong support values (PP, 1.00; MLBT, 100). The E. satelles and E. adhaerens subclade consisted of two strains of E. adhaerens, one strain of E. carterae and E. satelles respectively, and formed a strongly supported monophyletic lineage (PP, 1.00; MLBT, 100). The other clade consisted of 20 strains of $E$. deses and formed a monophyletic lineage with strong support values (PP, 1.00; MLBT, 100), and subdivided further into five lineages with strong support values except for the branch between D1 and D2 subclades (PP, 0.64; MLBT, 58).

\section{Species delimitation}

We used a species delimitation method (BP\&P) for 20 strains of $E$. deses based on the combined four-gene sequence dataset. Species delimitation results indicated in the species phylogeny (Fig. 1) and supported four cryptic species of $E$. deses (D1-D4; with SPP $=1.0$ for each clade) with one additional single taxa D5 . The result obtained from the species delimitation method was completely congruent with cell length parameter (Table 1, Fig. 1).

\section{Morphological observations}

The 32 strains of the E. deses group were observed using light microscopy and SEM (Table 1, Figs $2 \& 3$ ). The following morphological features for species identification in this group were analyzed: size and shape of the cell, size and shape of the chloroplast, paramylon type, location of the canal opening, shape of posterior end, presence of pyrenoid, and ornamentation of the pellicle (Table 1). All strains had common morphological features such as a cylindrically elongated cell shape, numerous discoid chloroplasts with a naked pyrenoid, and pronounced metaboly.

All of $E$. deses cells were worm-like and moved by metabolically bending or swimming. The anterior end was rounded with a laterally oriented canal opening (Figs 2A-F \& 3A-L). Free-swimming cells demonstrated a flagellum that was either nearly the same size of the body length or very short. The posterior end was rounded and tapered as acute or wedge. The diameter of the chloroplasts ranged from $4.9 \pm 0.4 \mu \mathrm{m}$ of the Daeriji010910A strain in D2 clade to $9.0 \pm 0.8 \mu \mathrm{m}$ of the Bihaksan031007A strain in D4 clade, and pyrenoid presence / visibility depended on the developmental state of the cell. Paramylon grains were rod-like or thick and brick-shaped and filled in the cytoplasm of the E. deses cells.

The $E$. deses cells were well grouped by cell dimension in each subclade resulted from the molecular phylogeny and species delimitation analysis. The D1 subclade was composed of five strains with (102.6 $\pm 12.5-137.3 \pm 15.2) \times$ $(10.3 \pm 2.8-12.1 \pm 1.5) \mu \mathrm{m}$ in dimension (Fig. 2A). The D2 subclade was consisted of two smallest strains with (77.5 $\pm 5.3-83.2 \pm 7.2) \times(7.7 \pm 0.8-10.0 \pm 1.4) \mu \mathrm{m}$ in dimension (Fig. 2B). The D3 subclade was consisted of six biggest strains with $(144.9 \pm 8.5-192.3 \pm 18.3) \times(12.1 \pm 1.9-18.5$ $\pm 2.3) \mu \mathrm{m}$ in dimension (Fig. 2C \& D). The subclade D4 was consisted of six strains with (83.4 $\pm 12.8-107.5 \pm 5.8)$ $\times(7.8 \pm 0.8-10.7 \pm 1.3) \mu \mathrm{m}$ in dimension (Fig. $2 \mathrm{E} \& \mathrm{~F})$. The subclade D5 was composed of only one strain with (171.9 $\pm 9.0) \times(17.2 \pm 3.5) \mu \mathrm{m}$ in dimension. The pellicular strips were very fine and spirally arranged (Fig. 3A-L). Adjoining strips were fused in the anterior end upon entering the canal opening (Fig. 3B, E \& H, arrowheads). The pellicle structure showed that the wide frame was depressed between two sharp processes; the strips therefore looked distinctly like double-tracked strips by SEM (Fig. 3C, F, I \& L, arrowheads).

The E. mutabilis cells were $(52.3 \pm 10.3-81.5 \pm 5.2) \times(7.9$ $\pm 0.4-10.4 \pm 1.2) \mu \mathrm{m}$ in dimension (Table 1, Fig. 2G). The canal opening was placed sub-apically, pellicular strips 


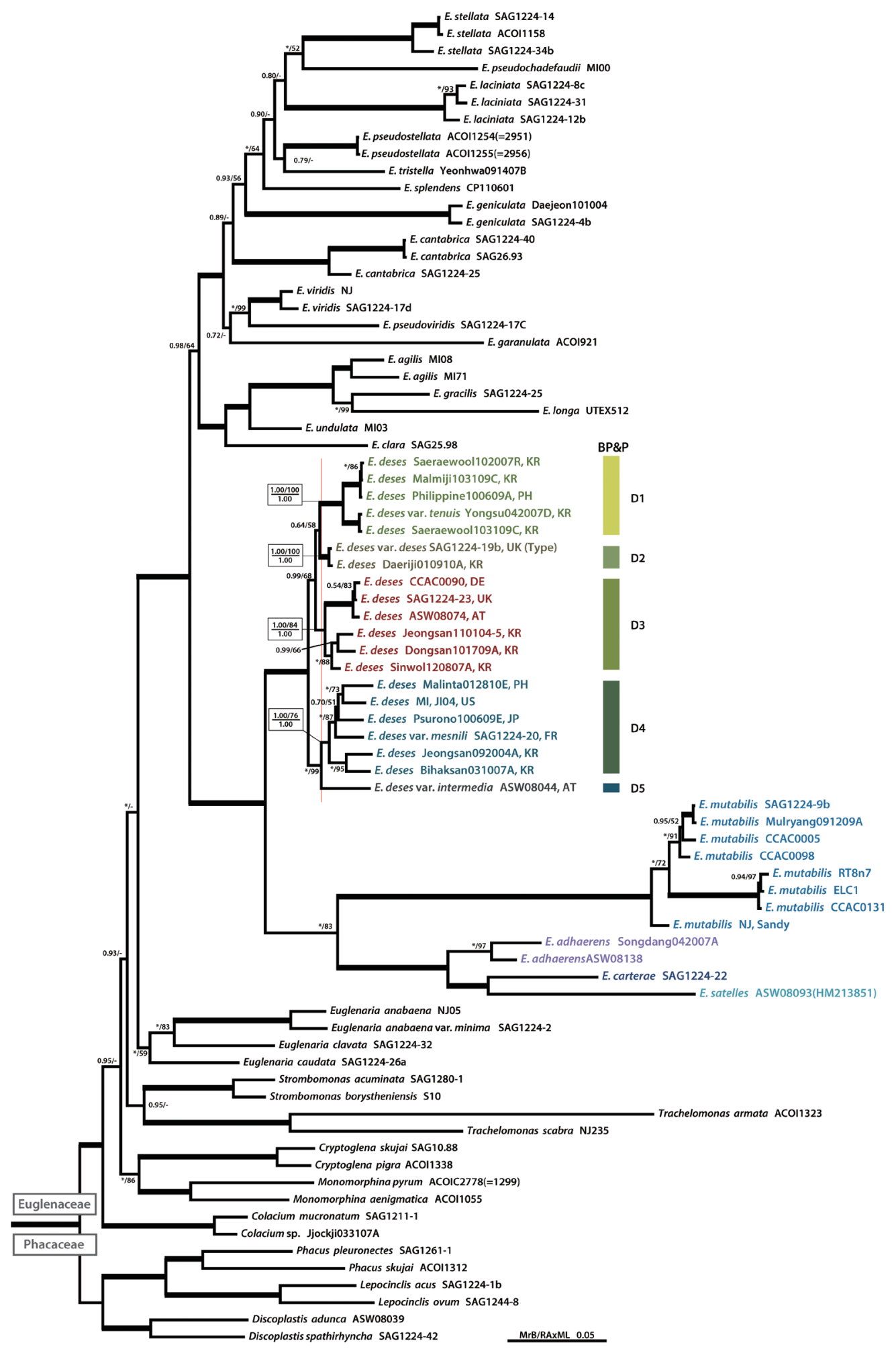

Fig. 1. Consensus Bayesian tree of the Euglena deses group based on combined nuclear small subunit, partial-large subunit, plastid small subunit, and partial-large subunit rDNA sequences. The tree was rooted with six family Phacaceae species as outgroups. The Bayesian posterior probability (PP) and maximum-likelihood bootstrap support value (MLBT) are shown above or below the branches. The bold branches indicate strongly supported values (PP, 1.00 and MLBT, 100\%). An asterisk refers to supported values (PP, 1.00 or MLBT, 100\%), and a dash indicates support values $<50 \%$. The bold branches indicate strongly supported values (PP, 1.00 and MLBT, 100\%). The speciation probabilities are provided for each node of BP\&P in box below the divider (speciation posterior probability for number of species; SPP[5], 1.00). The vertical red line indicates the speciation point, as estimated by the BP\&P. 


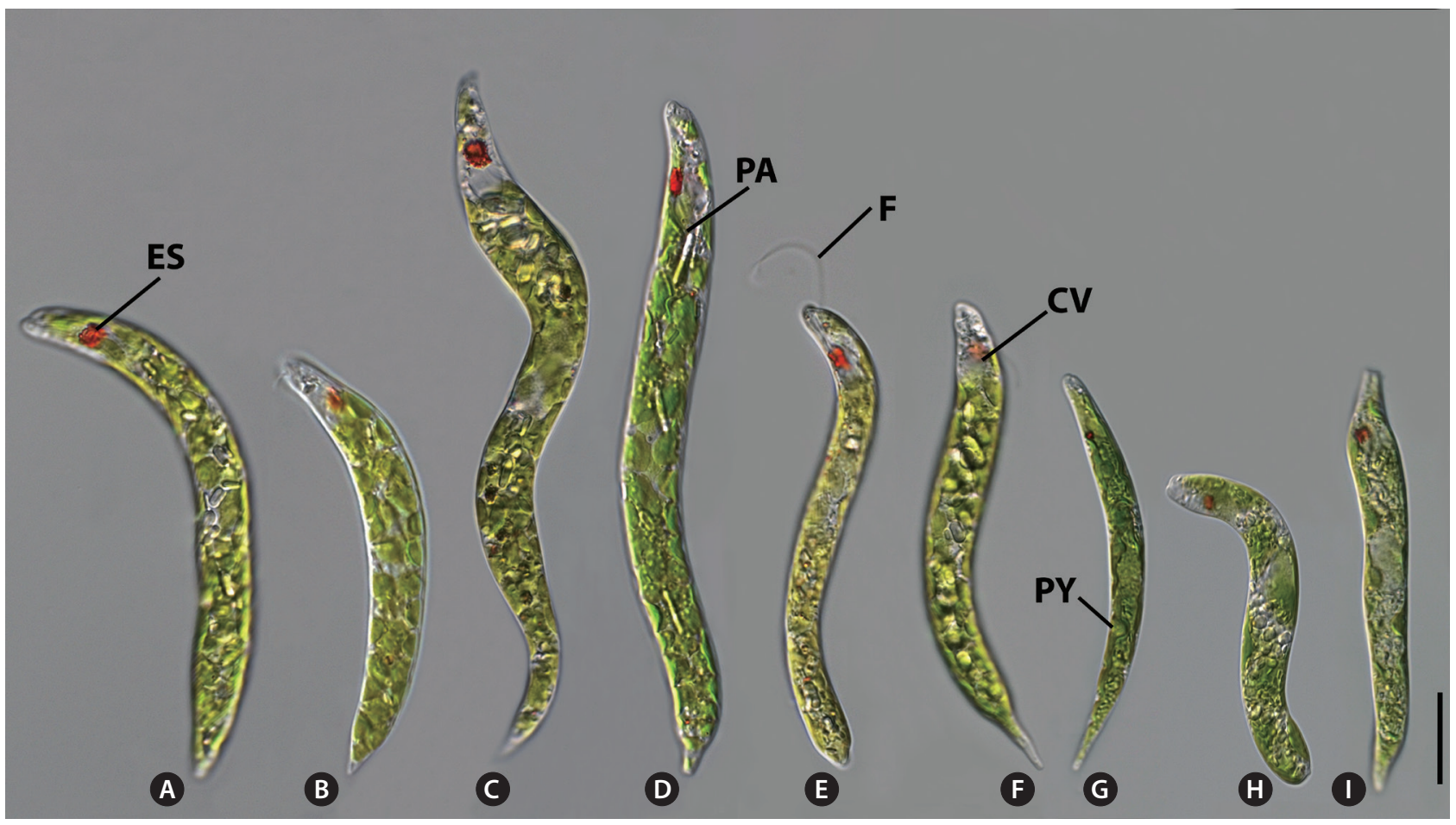

Fig. 2. Morphology of the Euglena deses species group. Cells demonstrated an eyespot (ES), a single emergent flagellum (F), a contractile vacuole $(\mathrm{CV})$, numerous rod-shaped paramylon grains $(\mathrm{PA})$, and numerous discoid chloroplasts with naked pyrenoids (PY). (A-F) E. deses. (A) Saeraewool103109C in D1 clade. (B) Daeriji010910A in D2 clade. (C) Jeongsan110104-5 in D3 clade. (D) Sinwoljunje120807A in D3 clade. (E) MI J04 in D4 clade. (F) Jeongsan092004A in D4 clade. (G) E. mutabilis Mulyoungari091209A. (H) E. carterae SAG1224-22. (I) E. adhaerens Songdang042007A. Scale bars represent: $20 \mu \mathrm{m}$.

reached into the canal, and the flagellum ended inside (Figs $2 \mathrm{G} \& 3 \mathrm{M}-\mathrm{O}$ ). The few chloroplasts were discoidshaped and $13.3 \pm 0.9-19.0 \pm 2.0 \mu \mathrm{m}$ in diameter. By SEM, the anticlockwise spirals of pellicular strips showed strict single stria in the middle part of the cell (Fig. 3M-O).

The E. carterae cells were $98.4 \pm 7.9 \mu \mathrm{m}$ in length and $10.4 \pm 1.3 \mu \mathrm{m}$ in width and were oblong and worm-like with a broad, obtuse and rounded posterior region (Fig. $2 \mathrm{H})$. The E. carterae SAG1224-22 cells demonstrated an apical canal opening and pellicular strips with double striae. Their movement was metabolic, bending and slowly creeping. The flagellum never exited the canal opening. Small ellipses paramylon grains filled the cell. The canal opening was positioned apically. The pellicular strips were not visible by light microscopy but showed faintly double strips under SEM (Fig. 3P-R, arrowheads). SEM revealed an anticlockwise arrangement of strips that became narrower near the canal opening, and pairs of strips became confluent before entering the canal (Fig. $3 \mathrm{P} \& \mathrm{Q})$.

The $E$. adhaerens cells were $92.8 \pm 9.0-124.1 \pm 8.2 \mu \mathrm{m}$ in length and $9.3 \pm 1.1-13.9 \pm 1.4 \mu \mathrm{m}$ in width. The few chlo- roplasts were discoid-shaped and $4.9 \pm 0.7 \mu \mathrm{m}$ in diameter. The canal opening was positioned apically, and the canal opening was terminal and clearly visible (Figs 2I, 3S \& T). Under SEM, the anticlockwise spirals of pellicular strips showed weak double striae in the middle part of the cell (Fig. 3S-U). The pellicle appeared more delicately striped near the anterior and posterior end. The strips became narrower but were not confluent before entering the canal.

\section{DISCUSSION}

Cryptic diversity in euglenoids has commonly been unveiled by molecular markers and in combination with morphological data (Kosmala et al. 2007b, 2009, Kim et al. 2013a, 2013b, Kim and Shin 2014). In this study, molecular reassessment revealed the presence of five cryptic lineages among 20 strains of $E$. deses using the Bayesian multi-locus species (BP\&P) delimitation method. Each lineage was adequately distinct from the others to regard them as separately evolving lineages. We validate the five 

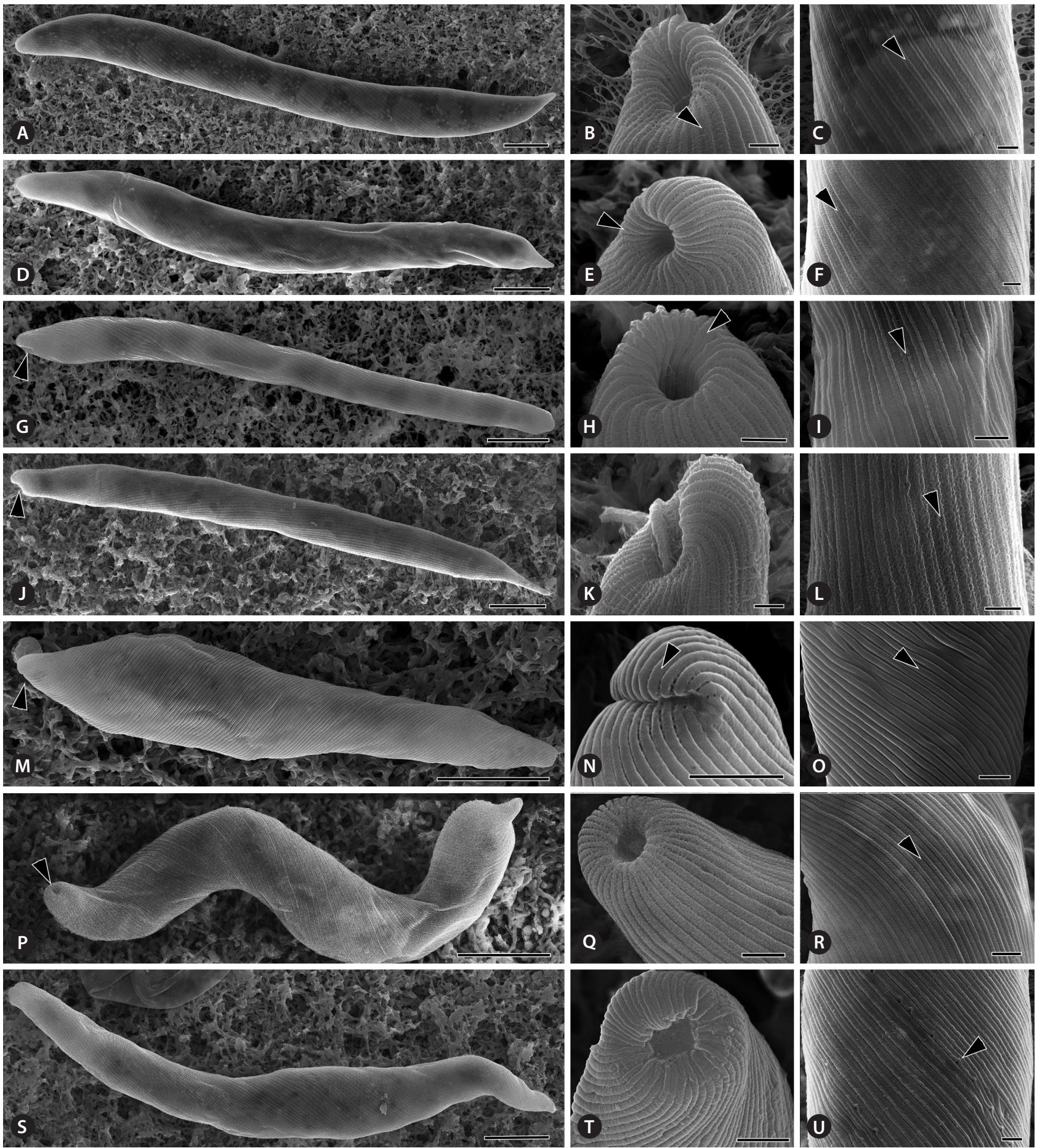

Fig. 3. Morphology of the Euglena deses group by scanning electron microscopy. All strains demonstrated cell shape, enlarged anterior end, and pellicular strips. (A-L) E. deses bearing an subapical anterior end ( $G$ \& J, arrowheads) double striae (B, C, E, F, H, I \& L, arrowheads) in pellicle strips. (A-C) E. deses Yongsu042007D in D1 clade. (D-F) E. deses Jeongsan110104-5 in D3 clade. (G-I) E. deses MI J04 in D4 clade. (J-L) E. deses Jeongsan092004A in D4 clade. (M-O) E. mutabilis Mulyoungari091209A bearing a subapical anterior end (M, arrowhead) and a single stria (N \& $\mathrm{O}$, arrowheads) in pellicle strips. (P-R) E. carterae SAG1224-22 bearing an apical anterior end (P, arrowhead) and double striae (R, arrowhead) in pellicle strips. (S-U) E. adhaerens Songdang042007A bearing an apical anterior end and a single (U, arrowhead) pellicle strip. Scale bars represent: A-U, $1 \mu \mathrm{m}$. 
species scenario for E. deses, and five clades (D1-D5) was also suggested by molecular data (as phylogeny and speciation probability results). Based on our data, this study largely supported a traditionally recognized and circumscribed E. deses sensu stricto species (D2 clade, included SAG1224-19b strain) as a distinct lineage. In addition, larger cell-sized strains were divided into four distinct lineages (D1, D3, D4, and D5 clades). The phylogenetic results were nearly congruent with that of species delimitation result suggested by species delimitation analysis. Therefore, our data supported that the size diversity of E. deses correspond to five clades by species delimitation method and may thus indeed represent closely related species.

Many taxonomic issues of $E$. deses has occurred as it is one of the most common species in the genus. Since being established by Ehrenberg (1835, 1838), Klebs (1883) erected a new variety, E. deses fo. intermedia, based on lack of pyrenoid. After that, many new forma and varieties were described based on cell dimension, chloroplast morphology with or without pyrenoid, paramylon morphology, and habitat (Lemmermann 1910, 1913, Playfair 1921, Wermel 1924, Fritsch et al. 1930, Deflandre and Dusi 1935, Pringsheim 1953, Popova 1955, Zakryś 1986, Shi 1989). Marin et al (2003) rejected the distinction of the authentic strain (SAG1224-20) of E. deses var. mesnili at the species level (E. mesnili) because the strain was positioned within the E. deses clade. More recently, Karnkowska-Ishikawa et al. (2011) synonymized many forma and varieties (E. deses var. intermedia, E. intermedia, E. intermedia var. klebsii, E. deses var. tennuis, E. deses var. gracilis, E. dese var. minuta, E. klebsii, E. intermedia var. brevis, E. dese fo. mesnili, E. intermedia fo. major, E. deses fo. klebsii, E. deses fo. digrana, E. intermedia var. acidophila) to only a species, E. deses. However, in this study E. deses strains were divided further into more than four lineages (Fig. 1, Supplementary Fig. S1) and matched well with size class (D1 clade, 103-137 $\mu \mathrm{m}$; D2, 78-83 $\mu \mathrm{m}$; D3, 145-192 $\mu \mathrm{m}$; D4, 83-108 $\mu \mathrm{m}$; D5, $172 \mu \mathrm{m}$ ). Pringsheim (1956) also tried to categorize his culture strains of $E$. deses based on cell size to four groups (group I-IV). However, he was not convinced about these size ranks because his clones seemed to show different dimensions of cell body and chloroplast. In euglenoids, morphological variations can occur in culture over long periods or in different environmental conditions (Popova 1966, Zakryśs et al. 2002, 2004, Kosmala et al. 2005, 2007a, 2007b, 2009, Karnkowska-Ishikawa et al. 2011). Therefore, our data largely coincided with that of Pringsheim (1956) and support that cell size is one of most important characters within the $E$. deses clade. In addition, many authors have recognized huge size differences in populations of E. deses (Ehrenberg 1835, 1838, Lemmermann 1910, Playfair 1921, Wermel 1924).

Other diagnostic characters, such as shape of posterior end and paramylon have been used as important characters to identify forma or varieties within E. deses (Pringsheim 1956, Zakryś 1986). In this study, the caudal and paramylon grain shape were not considered important characters because the strains with an acute, wedge, or rounded posterior ends were intermixed in $\mathrm{D} 2-\mathrm{D} 4$ clades, and the various paramylon grain shapes were not limited to a specific clade.

Recently, the papillae, forming rows of mucus along with pellicular strip, was used as a key character differentiating $E$. deses from other species within the group (Karnkowska-Ishigawa et al. 2011). When we observed the cells of $E$. deses, we could not see any papillae (dots or darken dots) even if the cells were stained with neutral red (Supplementary Fig. S1). However, when the cells were pressed by a coverslip as water becomes dry out, the mucus-like cytoplasmic fluids were produced (Supplementary Fig. S1B \& S1G). Therefore, the papillae may be an artifact and not a reliable diagnostic character for $E$. deses.

Another notable morphological feature among species of the E. deses group is the position of the canal opening. This morphological characteristic was congruent with our molecular phylogeny. Both E. deses and E. mutabilis demonstrated a lateral canal opening with a slight depression or lip. However, E. deses has a double pellicle strips with a wide median depression between the keel and the overhang, whereas E. mutabilis had a single stria. E. carterae, E. satelles, and E. adhaerens presented an apical canal opening. In particular, the anterior part of $E$. carterae was narrowly extended, and the canal opening was centrally positioned at the anterior end. Additionally, the strips were broader in E. satelles than E. carterae, and E. adhaerens demonstrated a plateau-like, flat frame of the strip along the entire cell (Fig. 3U).

E. deses var. carterae was established first by Pringsheim (1953) as a variety characterized by cell division in brackish water, the lack of a flagellum and the presence of a small stigma. Later, Marin et al. (2003) raised the variety E. deses var. carterae to the species E. carterae based on a molecular phylogenetic analysis showing its location outside of the $E$. deses clade as an independent clade. The morphological features of this species also indicated that $E$. carterae could be differentiated from $E$. deses by the presence of a pellicular ridge with a narrow strip (A or M-type) (Kusel-Fetzmann and Weidinger 2008). More 
recently, Karnkowska-Ishigawa et al. (2011) suggested that two species, E. carterae SAG1224-22 and E. satelles ASW08093, could be combined into E. satelles. However, our results did not support this idea, as these two stains were clearly separated according to morphological and molecular data. E. carterae SAG1224-22 and E. satelles ASW08093 showed a sister relationship in our tree (Fig. 1) and demonstrated unique pellicle strips; E. carterae had more narrow double striae in the pellicle strips than that of $E$. satelles. In addition, both species differ by $30 \mu \mathrm{m}$ in cell length (E. carterae SAG1224-22, $98.4 \pm 7.9 ;$ E. satelles ASW 08093, $128.3 \pm 9.5$ ).

We analyzed detailed morphological and molecular data among the $E$. deses group and observed a high morphological diversity among strains of $E$. deses in terms of cell size and tail shape. This study provides clear diagnostic data to identify the following five species by morphological and molecular analysis: E. deses (subapical anterior part, double striae), E. adhaerens (apical, weak double striae), E. carterae (apical, narrow double striae), E. satelles (apical, double striae), and E. mutabilis (apical, single stria). Molecular reassessment revealed the presence of five cryptic lineages in E. deses using the BP\&P species delimitation method and congruent with molecular phylogenetic result. This study supported five species of $E$. deses-like by morphological diagnostic characters, and assessed cryptic diversity within $E$. deses species.

\section{ACKNOWLEDGEMENTS}

This research was supported by Basic Science Research Program through the National Research Foundation of Korea funded by the Ministry of Science, ICT \& Future Planning (NRF-2013R1A1A3012539) to J. I. Kim and the Ministry of Education, Science and Technology (NRF2010-002273) to W. Shin.

\section{SUPPLEMENTARY MATERIAL}

Supplementary Table S1. Strains of the Euglena deses complex used in this study and the GenBank accession numbers for their nuclear SSU, LSU and plastid SSU, LSU rDNA gene sequenced (www.e-algae.org).

Supplementary Table S2. Evolutionary models, log likelihood values (-lnL), and model parameters resulted from each phylogenetic analyses for the combined data sets (www.e-algae.org).

Supplementary Fig. S1. Light micrographs of Euglena deses strains showing eyespot (ES), chloroplast (CP), paramylon (PA), pyrenoid (PY), pellicular strip (arrowheads), and papillae (arrows) (www.e-algae.org).

\section{REFERENCES}

Braslavska-Spectorova, E. P. 1937. Pro novii vid biezdjgoutivkovich evglen [Regarding a new species of $\mathrm{Eu}$ glena without flagella]. J. Inst. Bot. Acad. Sci. R. S. S. Ukraine 11:91-99.

Chu, S. P. 1946. Contributions to our knowledge of the genus Euglena. Sinensia 17:75-134.

Deflandre, G. \& Dusi, H. 1935. Description d'une Euglène nouvelle. Euglena mesnili nov. spec. Arch. Zool. Exp. Gén. 77:12-14.

Demchenko, E., Mikhailyuk, T., Coleman, A. W. \& Pröschold, T. 2012. Generic and species concepts in Microglena (previously the Chlamydomonas monadina group) revised using an integrative approach. Eur. J. Phycol. 47:264-290.

Ehrenberg, C. G. 1835 (1833). Dritter Beitrag zur Erkenntnis grosser Organisation in der Richtung des kleinsten Raumes. Phys. Abh. K. Akad. Wiss. Berlin 1833:145-336.

Ehrenberg, C. G. 1838. Die Infusionsthierchen als Vollkommene Organismen. Ein Blick in das Tiefere Organische Leben der Natur. Nebst Einem Atlas von Vierundsechszig Colorirten Kupfertafeln. Gezeichnet vom Verfasser. Verlag von Leopold Voss, Leipzig, 547 pp.

Fawley, M. W., Fawley, K. P. \& Hegewald, E. 2011. Taxonomy of Desmodesmus serratus (Chlorophyceae, Chlorophyta) and related taxa on the basis of morphological and DNA sequence data. Phycologia 50:23-56.

Fritsch, F. E., Rich, F. \& Stephens, M. E. L. 1930. Contribution to our knowledge of the freshwater algae of Africa. 7. Freshwater algae (exclusive of diatoms) from Griqualand West. Trans. R. Soc. S. Afr. 18:1-92.

Gojdics, M. 1953. The Genus Euglena. The University of Wisconsin Press, Madison, WI, $268 \mathrm{pp}$.

Greenwood, S. J., Schnare, M. N., Cook, J. R. \& Gray, M. W. 2001. Analysis of intergenic spacer transcripts suggests 'read-around' transcription of the extrachromosomal circular rDNA in Euglena gracilis. Nucleic Acids Res. 29:2191-2198.

Jo, B. Y., Shin, W., Kim, H. S., Siver, P. A. \& Andersen, R. A. 2013. Phylogeny of the genus Mallomonas (Synurophyceae) and descriptions of five new species on the basis of morphological evidence. Phycologia 52:266-278.

Karnkowska-Ishikawa, A., Milanowski, R. \& Zakryś, B. 2011. The species Euglena deses (Euglenaceae) revisited: new 
morphological and molecular data. J. Phycol. 47:653661.

Kim, J. I., Linton, E. W. \& Shin, W. 2015. Taxon-rich multigene phylogeny of the photosynthetic euglenoids (Euglenophyceae). Front. Ecol. Evol. 3:98.

Kim, J. I. \& Shin, W. 2007. Ultrastructure of Cryptoglena pigra from Korea. Algae 22:325-331.

Kim, J. I. \& Shin, W. 2008. Phylogeny of the Euglenales inferred from plastid LSU rDNA sequences. J. Phycol. 44:994-1000.

Kim, J. I. \& Shin, W. 2014. Molecular phylogeny and cryptic diversity of the genus Phacus (Phacaceae, Euglenophyceae) and the descriptions of seven new species. J. Phycol. 50:948-959.

Kim, J. I., Shin, W. \& Triemer, R. E. 2010. Multigene analyses of photosymthetic euglenoids and new family, Phacaceae (Euglenales). J. Phycol. 46:1278-1287.

Kim, J. I., Shin, W. \& Triemer R. E. 2013a. Cryptic speciation in the genus Cryptoglena (Euglenaceae) revealed by nuclear and plastid SSU and LSU rRNA gene. J. Phycol. 49:92-102.

Kim, J. I., Shin, W. \& Triemer R. E. 2013b. Phylogenetic reappraisal of the genus Monomorphina (Euglenophyceae) based on molecular and morphological data. J. Phycol. 49:82-91.

Klebs, G. 1883. Über die Organisation einiger FlagellatenGruppen und ihre Beziehungen zu Algen und Infusorien. Untersuchungen Bot. Inst. Tübingen 1:233-362.

Kosmala, S., Bereza, M., Milanowski, R., Kwiatowski, J. \& Zakryś, B. 2007a. Morphological and molecular examination of relationships and epitype establishment of Phacus pleuronectes, Phacus orbicularis and Phacus hamelii. J. Phycol. 43:1071-1082.

Kosmala, S., Karnkowska, A., Milanowski, R., Kwiatowski, J. \& Zakryś, B. 2005. Phylogenetic and taxonomic position of Lepocinclis fusca comb. nov. (=Euglena fusca) (Euglenaceae): morphological and molecular justification. J. Phycol. 41:1258-1267.

Kosmala, S., Karnkowska-Ishikawa, A., Milanowski, R., Kwiatowski, J. \& Zakryś, B. 2009. Phylogeny and systematics of Euglena (Euglenaceae) species with axial, stellate chloroplasts based on morphological and molecular data: new taxa, emended diagnoses and epitypifications. J. Phycol. 45:464-481.

Kosmala, S., Milanowski, R., Brzóska, K., Pękala, M., Kwiatowski, J. \& Zakryś, B. 2007b. Phylogeny and systematics of the genus Monomorphina (Euglenaceae) based on morphological and molecular data. J. Phycol. 43:171185.

Kusel-Fetzmann, E. \& Weidinger, M. 2008. Ultrastructure of five Euglena species positioned in the subdivision Serpentes. Protoplasma 233:209-222.

Leedale, G. F. 1967. Euglenoid flagellates. Concepts of modern biology series. Prentice-Hall Inc., Englewood Cliffs, NJ, 242 pp.

Leedale, G. F. 1982. Ultrastructure. In Buetow, D. E. (Ed.) The Biology of Euglena, Vol. III. Physiology. Academic Press, New York, pp. 1-27.

Lemmermann, E. 1910. Kryptogamenflora der Mark Brandenburg. III. Algen. Verlag von Gebrüder Borntraeger, Leipzig, $712 \mathrm{pp}$.

Lemmermann, E. 1913. Eugleninae. In Pascher, A. (Ed.) Die Süsswasserflora Deutschlands, Österreichs und der Schweiz. H. 2: Flagellatae II. Verlag von Gustav Fisher, Jena, pp. 115-174.

Lewis, L. A. \& Flechtner, V. R. 2004. Cryptic species of Scenedesmus (Chlorophyta) from desert soil communities of western North America. J. Phycol. 40:1127-1137.

Linton, E. W., Karnkowska-Ishikawa, A., Kim, J. I., Shin, W., Bennett, M. S., Kwiatowski, J., Zakryś, B. \& Triemer, R. E. 2010. Reconstructing euglenoid evolutionary relationships using three genes: nuclear SSU and LSU, and chloroplast SSU rDNA sequences and the description of $E u$ glenaria gen. nov. (Euglenophyta). Protist 161:603-619.

Lundholm, N., Bates, S. S., Baugh, K. A., Bill, B. D., Connell, L. B., Léger, C. \& Trainer, V. L. 2012. Cryptic and pseudocryptic diversity in diatoms: with descriptions of Pseudo-nitzschia hasleana sp. nov. and P. fryxelliana sp. nov. J. Phycol. 48:436-454.

Mainx, F. 1927. Beiträge zur Morphologie und Physiologie der Eugleninen. I. Morphologische Beobachtungen. Methoden und Erfolge der Reinkultur. Arch. Protistenkd. 60:305-414.

Mann, D. G., McDonald, S. M., Bayer, M. M., Droop, S. J. M., Chepurnov, V. A., Loke, R. E., Ciobanu, A. \& du Buf, J. M. H. 2004. The Sellaphora pupula species complex (Bacillariophyceae): morphometric analysis, ultrastructure and mating data provide evidence for five new species. Phycologia 43:459-482.

Marin, B., Palm, A., Klingberg, M. \& Melkonian, M. 2003. Phylogeny and taxonomic revision of plastid-containing euglenophytes based on SSU rDNA sequence comparisons and synapomorphic signatures in the SSU rRNA secondary structure. Protist 154:99-145.

Matvienko, O. M. 1938. Materiali do vivtchennia vodorostii URSR (Contributions to the study of the algae of the Ukraine USSR). Tr. N. D. Inst. Bot. Kharkov 3:29-70.

Monfils, A. K., Triemer, R. E. \& Bellairs, E. F. 2011. Characterization of paramylon morphological diversity in photosynthetic euglenoids (Euglenales, Euglenophyta). Phy- 
cologia 50:156-169.

Playfair, G. I. 1921. Australian freshwater flagellates. Proc. Linn. Soc. N. S. W. 46:99-146.

Popova, T. G. 1955. Euglenovyje vodorosli. Opredelitel' prosnovodnych vodoroslej SSSR, 7 [Euglenophyta. The handbook offreshwater algae of the USSR, 7]. Sovetskaya Nauka, Moskva, 267 pp. (in Russian).

Popova, T. G. 1966. Euglenophyta 1. Flora Plantarum USSR. 8. Nauka, Moskva-Leningrad, 411 pp. (in Russian).

Pringsheim, E. G. 1953. Salzwasser-Eugleninen. Arch. Microbiol. 18:149-164.

Pringsheim, E. G. 1956. Contributions towards a monograph of the genus Euglena. Nova Acta Leopold. 18:1-168.

Ronquist, F., Teslenko, M., van der Mark, P., Ayres, D. L., Darling, A., Höhna, S., Larget, B., Liu, L., Suchard, M. A. \& Huelsenbeck, J. P. 2012. MrBayes 3.2: efficient Bayesian phylogenetic inference and model choice across a large model space. Syst. Biol. 61:539-542.

Schmitz, F. 1884. Beiträge zur Kenntnis der Chromatophoren. Pringsh. Jahrb. Wiss. Bot. 15:1-175.

Schnare, M. N. \& Gray, M. W. 2011. Complete modification maps for the cytosolic small and large subunit rRNAs of Euglena gracilis: functional and evolutionary implications of contrasting patterns between the two rRNA components. J. Mol. Biol. 413:66-83.

Shi, Z. 1989. A new variety of Euglena intermedia inhabiting acid water. Acta Hydrobiol. Sin. 13:287-288.

Shin, W. \& Boo, S. M. 2001. Ultrastructure of Phacus trypanon (Euglenophyceae) with an emphasis on striated fiber and microtubule arrangement. J. Phycol. 37:95-105.

Shin, W. \& Triemer, R. E. 2004. Phylogenetic analysis of the genus Euglena (Euglenophyceae) with particular reference to the type species Euglena viridis. J. Phycol. 40:759-771.

Škaloud, P., Kynčlová, A., Benada, O., Kofroňová, O. \& Škaloudová, M. 2012. Toward a revision of the genus Synura, section Petersenianae (Synurophyceae, Heterokontophyta): morphological characterization of six pseudo-cryptic species. Phycologia 51:303-329.

Škaloud, P., Škaloudová, M., Procházková, A. \& Němcová, Y. 2014. Morphological delineation and distribution patterns of four newly described species within the Synura petersenii species complex (Chrysophyceae, Stramenopiles). Eur. J. Phycol. 49:213-229.

Smith, S. W., Overbeek, R., Woese, C. R., Gilbert, W. \& Gillevet, P. M. 1994. The genetic data environment: an expandable GUI for multiple sequence analysis. Comput. Appl.
Biosci. 10:671-675.

Stamatakis, A. 2014. RAxML version 8: a tool for phylogenetic analysis and post-analysis of large phylogenies. Bioinformatics 30:1312-1313.

Triemer, R. E. 1980. Role of Golgi apparatus in mucilage production and cyst formation in Euglena gracilis (Euglenophyceae). J. Phycol. 16:46-52.

Triemer, R., Linton, E., Shin, W., Nudelman, A., Monfils, A., Bennett, M. \& Brosnan, S. 2006. Phylogeny of the Euglenales based upon combined SSU and LSU rDNA sequence comparisons and description of Discoplastis gen. nov. (Euglenophyta). J. Phycol. 42:731-740.

Walne, P. L., Moestrup, Ø., Norris, R. E., \& Ettl, H. 1986. Light and electron microscopical studies of Eutreptiella eupharyngea sp. nov. (Euglenophyceae) from Danish and American waters. Phycologia 25:109-126.

Watanabe, M. M. \& Hiroki, M. 1997. NIES-Collection: list of strains. 5th ed. National Institute for Environmental Studies, Tsukuba, $127 \mathrm{pp}$.

Wermel, E. 1924. Neue order wenig bekannte Protisten XII. Neue order wenig bekannte Flagellaten XI. Beschreibung neuer Flagellaten aus Russland. Arch. Protistenkd. 48:204-206.

Wuyts, J., De Rijk, P., Van de Peer, Y., Winkelman, T. \& De Wachter, R. 2001. The European large subunit ribosomal RNA database. Nucleic Acid Res. 29:175-177.

Yang, Z. \& Rannala, B. 2014. Unguided species delimitation using DNA sequence data from multiple loci. Mol. Biol. Evol. 31:3125-3135.

Zakryś, B. 1986. Contribution to the monograph of Polish members of the genus Euglena Ehrenberg 1830. Nova Hedwig. 42:491-540.

Zakryś, B., Cambra-Sanchez, J. \& Walne, P. L. 2001. Chloroplast ultrastructure of Euglena cuneata Pringsheim, E. deses Ehrenberg and E. mutabilis (Euglenophyceae): taxonomic significance. Acta Protozool. 40:161-167.

Zakryś, B., Empel, J., Milanowski, R., Gromadka, R., Borsuk, P., Kędzior, M. \& Kwiatkowski, J. 2004. Genetic variability of Euglena agilis (Euglenophyceae). Acta Soc. Bot. Pol. 73:305-309.

Zakryś, B., Milanowski, R., Empel, J., Borsuk, P., Gromadka, R. \& Kwiatowski, J. 2002. Two different species of Euglena, E. geniculata and E. myxocylindracea (Euglenophyceae), are virtually genetically and morphologically identical. J. Phycol. 38:1190-1199. 